\title{
Reconsidering the Stigma of Political Opportunism Among the Kiai: A Critique of the Modernist Perspective
}

\section{Suswanta ${ }^{1}$}

Received: 14 March 2018 | Accepted: 28 May 2018 | Published: 5 June 2018

\begin{abstract}
This study is rooted in a deep dissatisfaction with research that stigmatises the political activities of kiai as opportunist. Using an empirical basis, this article examines the political activities of the kiai during the internal conflicts of the Partai Kebangkitan Bangsa (PKB, National Awakening Party), hoping to show that the political activities of kiai are not opportunistic. Bourdieu's theory of social practice, with its conceptual framework (i.e. habitus, field, and capital) is borrowed to examine the political activities of kiai. This article presents qualitative research using an emic approach. Data was collected through in-depth interviews, observations, and document studies. This study finds that the political activities of the kiai during the PKB's internal conflicts were not opportunistic but rather a social praxis, unique in its representation of dialectic between the kiai's symbolic capital within the $P K B$ and their application of their pesantren habitus and the Islamic value of Ahlusunnah wal jamaah (Aswaja). Politics, as viewed by the kiai, is a tool for realising truth and justice (Iqomatul Haq wal 'adl). They attempted to create balance by applying their pesantren habitus in political life to ensure that the PKB continued to follow the values of Aswaja Islam. The kiai, who had previously supported Gus Dur in the PKB's first internal conflict, became critical and shifted their support to Alwi Shihab during the PKB's first internal conflict, advising Gus Dur to control his ego, position himself correctly, and be consistent in his speech and actions while leading and administering the PKB.
\end{abstract}

Keywords: Politics, Kiai, Pesantren, Habitus, Conflict

\section{Introduction}

Research into the political activities of the kiai in the Islamic organisation Nahdlatul Ulama (henceforth NU) has often involved stigmatisation. A negative portrayal of kiai's political activities during the Old Order was presented, for example, by Ernst Utrecht (1959),

Lecturer in Department of Government Science, Faculty of Social and Political Sciences, Universitas Muhammadiyah, Yogyakarta. 
who identified NU as an extremely opportunistic party. Similarly, Mochtar Naim suggested that the NU acted opportunistically in its political activities (Naim, 1960, p.159). Daniel Lev (1966) wrote that the opportunism of the NU was widely accepted, despite some leaders being excessively opportunistic. ${ }^{2}$ Arnold Brackman depicted the organisation as a free agent that frequently affiliated itself with the highest bidder, willing to work with anyone, even the Partai Komunis Indonesia (PKI, Communist Party of Indonesia), so long as their financial demands were met and their religious sensitivities were not disturbed (Brackman, 1963, p.173). ${ }^{3}$ Similar opportunism during the New Order was described by Munir Mulkan, who argued that NU used a fiqhiyah approach to legislate religion in accordance with its theological understandings in the face of its objective sociopolitical situation. As a result of this approach, the political attitudes and behaviours of NU changed drastically. Where, in the 1982 election and previously, NU had issued a fatwa (decree) requiring Muslims to vote for Indonesia's Islamic party, in the 1987 election the organisation issued an opposite fatwa, requiring members to vote for the dominant Partai Golongan Karya (Golkar, Working Groups Party). ${ }^{4}$

Rooted in dissatisfaction with this stigmatisation, ${ }^{5}$ this study uses an empirical basis to examine the shift in political support among the kiai khos during PKB's second internal conflict. This shift in support, from Abdurrahman Wahid (Gus Dur) to Alwi Shihab, is interesting to consider for several reasons. First, somesuch as Kamarudin (2013), Imam Suherman, and Firman Noor

See also Lev, 1966, pp. 105-263.

3 For further detail, see Fealy, 2009, pp. 4-7. One kiai and NU politician considered opportunist is KH. Idham Chalid. Also see Fealy in Muhajir 2007, pp. ix-xiii.

4 For further discussion, see Mulkan, 1992 p. 114.

5 Inspired by Fealy, 2009, pp. 1-15. Fealy wrote that two main academic discourses have emerged regarding the historiography of the NU. The first is critical of the NU, and may be considered dominated by modernist discourses. The second, which uses a sympathetic approach, may be considered a discourse that respects tradition.

6 Imam Suherman and Firman Noor, Resolusi Konflik Partai Kebangkitan Bangsa: Studi Kasus Tahun 2008-2011, Seminar Paper, Faculty of Political Sciences, University of Indonesia, 2013. 
have considered this a form of opportunism, which they claim characteristic of NU. This study, however, indicates that the PKB's second internal conflict was rooted in the pragmatic issue of which position best reflected the party's foundational values. Second, the kiai khos were created and popularised as a group by Gus Dur to improve his bargaining power with the Central Axis. The kiai khos were senior religious leaders who provided religious knowledge to the members of NU. They had long supported the policies and political activities of Gus Dur, including in the PKB's first internal conflict. This study uses Bourdieu's concepts of habitus, field, and capital to examine the shifting political support of the kiai khos during the PKB's second internal conflict and show that it was not opportunistic.

\section{Understanding the Modernist Perspective}

Behind the critique of the kiai khos and their shift in political support as opportunistic is a dominant modernist perspective. This perspective is one used by people "outside" NU to understand the political activities of the kiai through an etic approach (scientist point of view), i.e. with distance between the observer and the observed. This modernist perspective assumes that kiai, as economic beings, only consider their own benefits and interests. This perspective represents the rational choice theory promoted by James S. Coleman (2010), as well as the social exchange theory of George C. Homans (Ritzer, 2012). In the theory of rational choice, human beings are assumed to actively choose actions that will maximise their profits/benefits while minimising their costs/losses. Meanwhile, the theory of social exchange explains the principle of rational choice by assuming that human social behaviours represent the exchange between two parties, the seen and unseen, and frequently manifested through the negotiation of cost and reward. According to this theory, in 
dealing with outside offers, individuals are motivated essentially by calculations of cost and reward. As such, human behaviour is at its essence economic (material/non-material), intended to reap the most reward for the least cost (Anand, Pattanaik, and Puppe, 2009, p. 156; see also Bungin, 2007, p.40).

The main supporters of such a perspective are modernist Muslims in Indonesia, as well as Western scholars and observers. Modernist Muslims may be defined as those who support the reformist movements that began to emerge and develop in the late 19th century, characterised by an acceptance of ijtihad, ${ }^{7}$ the adoption of modern technology, and the "purification" of Islam from syncretic cultural elements (Asyari, 2010, p.16; see also Noer, 1994, p.114). These modernists are committed to removing nonIslamic elements from the faith, and adapting Islamic teachings to accommodate modern technology, organisations, and education. They criticise the religious faith and traditional practices, which they see as not being based on Islam's primary sources, mixing Islamic doctrine with non-Islamic teachings, and distancing Muslims from the true spirit of Islam. In their opinion, traditionalist Muslims seek only to promote their personal and community interests through their political activities. Such a perspective informs the negative stereotyping of kiai's political activities as mentioned above.

The modernist perspective's greatest weakness is its tendency to negatively characterise religious practices and the traditional political behaviours of religious leaders. This perspective also ignores the fact that religious leaders, in this case the kiai, do not exist within only one world. Studies have identified many models and types of kiai. For example, Suprayogo (1998) identifies four types of kiai. First, spiritual kiai, the kiai who only administer and teach at pesantren (Islamic boarding schools) and concentrate on

The word ijtihad denotes 'an opinion or interpretation'. It indicates the use of one's abilities and mind to consider the rules embedded within the Qur'an, following certain criteria. A mujtahid is a person who does ijtihad. See Team for the Formulation of the Greater Dictionary of the Indonesian Language. (Ijtihad, 1990). 
worship. Second, advocate kiai, those kiai who teach actively at pesantren but are also concerned with social empowerment. Third, adaptive political kiai, those kiai who are close to the government and show concern for political organisation and power. Fourth, critical political kiai, those kiai who show concern for political organisation and power, but are critical of the government. A different classification of kiai has been offered by Turmudi (2004) and Wartono (2003). Seeing kiai leadership as generally focusing attention on cultural and political aspects, Turmudi identifies kiai as kiai pesantren, kiai tarekat, kiai politik, and kiai panggung. ${ }^{8}$ Aside from this diverse typology, there is de facto evidence that the kiai have contribute roles in their communities. Clifford Geertz (1959), for example, writes that kiai serve as cultural brokers, holding back the negative influences of cultural transformations on social life. Meanwhile, Hiroko Horikoshi (1987) writes that the kiai do not serve as mere cultural brokers, but also as bringers of change and balance in the midst of modernisation. Kiai are respected individuals and problem solvers in their communities.

As such, it is not simple to generalise about the political activities of kiai, given their diverse classifications and roles. Kiai may occupy diverse roles depending on their educational, economic, cultural, political, and leadership backgrounds. Likewise, their different levels of devotion can be seen from their educational background and knowledge of Islam, as well as their positions within Islamic organisations. This all indicates the complexity of investigating kiai and the traditional power relations between

A kiai pesantren is a kiai focused primarily on teaching at the pesantren. Such kiai are greatly respected by santri and by the communities around the pesantren. Kiai tarekat are those who focus their activities on developing the mind and heart. Kiai politik are those involved in practical politics to further the NU. Meanwhile, kiai panggung are those kiai who seek to promote Islamic dakwah through sermons. Turmudi's research also indicates that, in reality, a kiai may fall under more than one category. A kiai politik may simultaneously be a kiai pesantren and a kiai panggung, or a kiai tarekat may serve simultaneously as a kiai pesantren. Similarly, Wartono identifies three categories of kiai: organic intellectuals, traditional intellectuals, and simultaneous intellectuals. These categories were formulated based on research into the function of the kiai within the state under Gus Dur, using a Gramscian perspective. 
them (Dirjosantoso, 1999). ${ }^{9}$ Based on this explanation, the stigma of opportunism with which kiai have been branded, seems quite shallow. Modernism suffers the fallacy of dramatic instance, owing to its tendency for overgeneralisation, using only one or two cases to make a general argument.

Table 1:

Assumptions, Characteristics, and Shortcomings of the Modernist Perspective

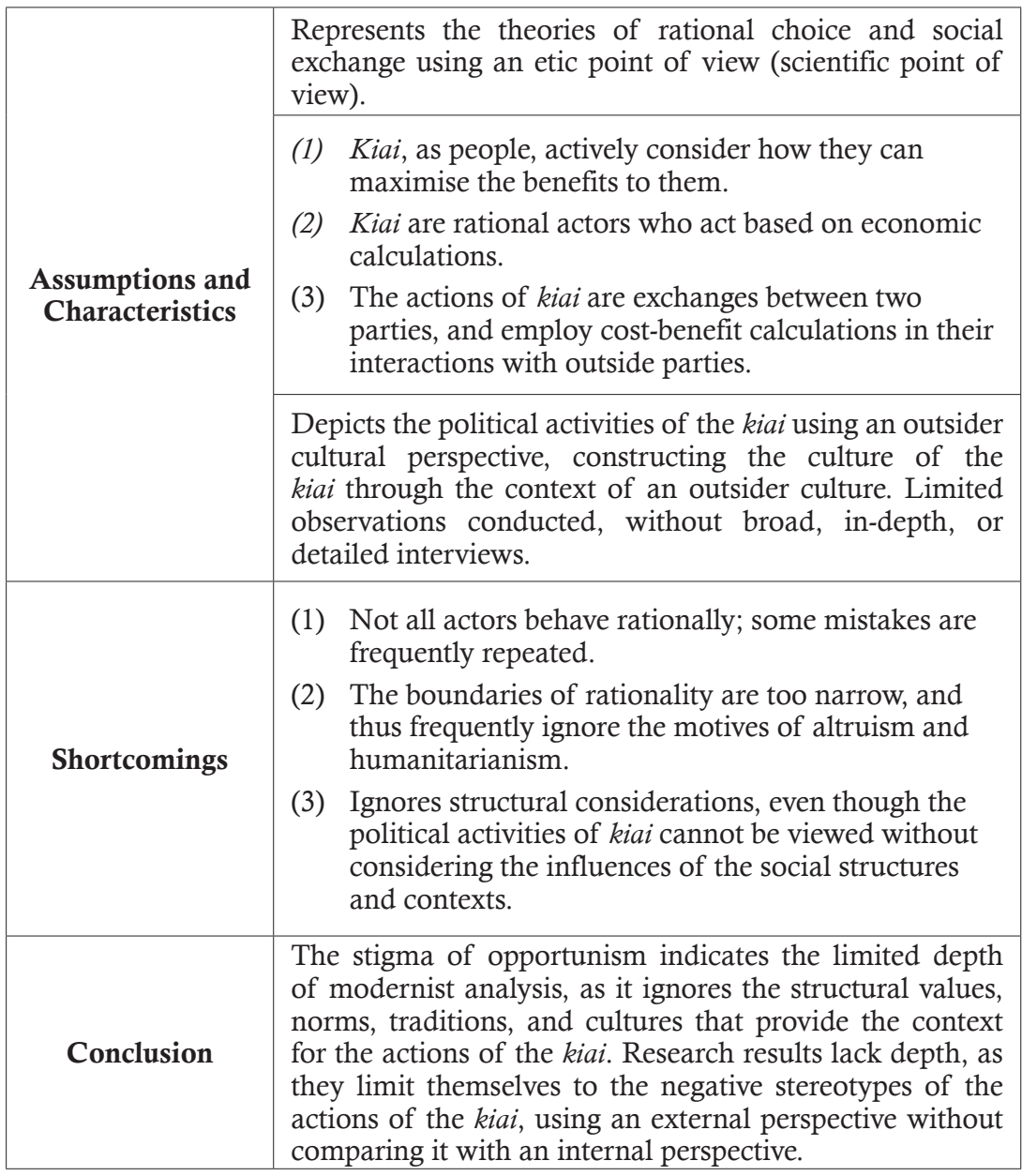

$9 \quad$ As writen by Abdurrahman Wahid, in Introduction pp. xii-xiii. 


\section{Habitus and the Pesantren Field}

Bourdieu's theory of social practice and its conceptual framework (habitus, field, and capital) are used here to examine the political activities of the kiai khos during the PKB's second internal conflict. Bourdieu defines habitus as a subjective structure, one internalised within one's unconscious mind (Bourdieu, 1992, p.53). Field, meanwhile, is an objective structure, in which people establish relations and practice their individual habitus (Bourdieu \& Waqcuant, 1992, p. 97). Capital, meanwhile, is the capacity and property possessed by someone, which determines its position in the social hierarchy and social relations (Bourdieu, 1984, p. 112). There are four types of capital: social capital, economic capital, cultural capital, and symbolic capital. According to Bourdieu, habitus, field, and capital are all interlinked, and create what may be termed social practice.

Habitus, field, and capital are described as forming a structuring structure, one that depicts people as influencing and changing their environment, as well as a structured structure, as a space in which social interactions are produced by people's behaviour. Habitus can only be manifested within practice, and are highly influenced by the capital possessed by agents, while the field is an expansive structure in which the habitus is situated. For Bourdieu, habitus is a system of dispositions, influenced by agents' backgrounds and classes. According to Bourdieu, once habitus is formed, it tends to serve as a reference or guideline for agents' actions, as habitus is enduring. However, at a certain point, habitus must adapt to the field, and as the field changes the habitus also changes. As the kiai khos are part of the pesantren community, their activities are guided by the pesantren habitus, characterised by simple living, surrender, zuhud, tawaddlu', and life as worship, as well as a devotion to upholding the truth and justice; this latter point serves as an important influence on the political activities of the kiai.

Habitus is constructed through three elements: processes, 
personality, and social logics (Bourdieu, 1984, p.24). These three aspects thus shape the views of the santri (students at pesantren) and would-be kiai. For example, the political views of kiai are continuously socialised using various arguments, both scientific and religious, such as through the passing of fatwa mandating certain behaviours among communities. Such fatwa shape the personalities of the santri, who respect the kiai for their attitudes, speech patterns, and comportment. This personality shapes their logic, and after the santri graduate and leave the pesantren they use this logic when interacting with their communities. In other words, the education received at the pesantren shapes the habitus of the santri (Febrina, Mustika \& Dedees, 2014).

In pesantren, the kiai occupy a special and honoured position. Their everyday behaviours and activities offer guidance to the santri and to the local communities. The kiai are perceived as being devout individuals, with extensive religious knowledge and better character than ordinary people. As the kiai khos were born, educated, and raised in a pesantren context, their positions and habitus were quite similar. Of the three kiai khos with important roles in NU during the period studied, only K. H. Abdullah Faqih held social and academic networks that reached the religious scholars in Saudi Arabia, as he had studied in Mecca under Sayyid Alwi bin Abbas al Maliki. These networks gave him greater capital in a pesantren context. Meanwhile, K. H. Mas Muhammad Subadar and K. H. Abdurrahman Chudlori only had social and cultural capital among the nahdliyin, pesantren, and their communities. It was the social, cultural, and symbolic capital of K. H. Abdullah Faqih that gave him an edge over the other kiai khos when a leader was chosen for the Langitan Forum.

Within NU pesantren, there is a phrase sami'na wa atho'na (I listen, and I obey). This phrase indicates the patronistic relations between the kiai and the santri. The santri are expected to tawadlu' the kiai not only in spiritual affairs, but also in worldly affairs, including political affairs. The santri do not only respect the kiai, but also their sons and even their grandsons. In the context of such 
patronistic relations, the three kiai khos were the leaders of pesantren with thousands of students. K. H. Abdullah Faqih led the Langitan pesantren in Tuban, K. H. Mas Muhammad Subadarled the Roudlatul Ulum pesantren in Pasuruan, and K. H. Abdurrahman Chudlori led the API pesantren in Tegalrejo, Magelang. Langitan is the oldest pesantren in East Java, and as such occupies a central position. It has produced numerous kiai who have gone on to establish their own pesantren, including K. H. Hasyim Asy'ari, the grandfather of Gus Dur, founder of NU, and the Tebuireng pesantren in Jombang. K. H. Chudlori, the father of K. H. Abdurrahman Chudlori, was a student of this pesantren. Based on the networks discussed here, it is clear that the NU kiai were one large family, united not only by Aswaja Islam, but also kinship bonds. These bonds were an important part of the kiai's existence.

\section{Capital in the Power Relations of the Kiai}

The legitimacy of the kiai within pesantren is strongly determined by the capital they hold. Bourdieu recognises four types of capital, all of which may be held by a kiai: economic, social, cultural, and symbolic. The land owned by pesantren, as well as the various means of production and finance are considered economic capital. This is the most easily converted to other forms of capital. Social networks and kinship bonds between kiai and social position are considered social capital. Knowledge of religion and its transmission, including the preparation of diplomas, tsaqofah, speaking and writing abilities, as well as rhetoric, are considered forms of cultural capital. Charisma, the titles of kiai khos or Wali Allah (Waliyullah), and elements related to symbolic power such as official positions, titles, and social/institutional consecration are included as symbolic capital.

According to Bourdieu, every field contains a dominant and dominated group. Dominance is determined by the situations, strategies, and capitals possessed by agents, which shape the power 
relations between them. Capital, thus, is the principle cause of differentiation and hierarchisation within the field (Bourdieu, 1995). In NU tradition, kiai khos occupy a special position and are greatly honoured. They occupied such a dominant because they possessed all forms of capital, not only social (pesantren networks), cultural (genealogy and knowledge), and symbolic (titles and prestige) capital, but also financial capital. These kiai khos are descended from the great kiai, owners of large pesantren and their facilities. However, studies have found that cultural and symbolic capital are more prominent in the legitimisation of kiai than social and economic capital. Dirdjosanjoto (1999), for example, notes that the legitimacy of kiai power is founded primarily on their command of cultural and symbolic capital. The greater the knowledge of a kiai, the greater his potential charisma; the greater the charisma of the kiai, the greater his power and influence (Horikoshi, 1987).

The involvement of kiai in the PKB indicated an expansion in the space in which they could become active, reaching from the pesantren to politics. The political openness following the end of the New Order offered NU members the ability to establish their own political party, one through which they could channel their aspirations. Although its establishment was coloured by controversy, the PKB represented NU's response to its decades-long lack of a vehicle for conveying and manifesting its political aspirations. This party was able to stimulate the kiai, making them more active in political abilities than they had been in the New Order era. The kiai enthusiastically supported the establishment of the PKB, certain that it would further the interests of Muslims and the greater good of the nation, reflecting the status of Islam as rahmatan lil 'alamiin (a blessing for all). They saw it necessary to promote the values of Aswaja Islam using a political approach.

NU's expansion into the political sphere brought with it changes in patterns of dominance and the role of capital. K. H. Abdurrahman Wahid (henceforth Gus Dur) took a dominant position within the $\mathrm{PKB}$, replacing the kiai. His dominance indicates 
the importance of social capital, along with cultural and symbolic capital. The kiai and Gus Dur possessed a relatively similar habitus. Although Gus Dur was also influenced by the habitus of the Arab and Western world, the pesantren habitus remained dominant. Gus Dur and kiai khos also occupied similar economic positions. They were all descended from great kiai who owned expansive pesantren and their facilities. However, they had different social, cultural, and symbolic capitals. Gus Dur had more social and cultural capital than the kiai khos, resulting primarily from his intellectual capabilities and genealogy. He occupied a dominant position owing to his networks, patron-client relations, habitus (resulting from pesantren, Arab, and Western influences), as well as his ability to speak and work together with different religious, ethnic, national, and ideological groups. As the son of a government official (specifically, Minister of Religion), from his youth Gus Dur had interacted with diverse groups visiting his father. Gus Dur's symbolic capital was also stronger than that of the kiai khos, as he was known not only as a kiai, but also as a scholar, cultural critic, and politician.

According to Bourdieu, to improve one's position within the field, one can exchange or convert one form of capital for another. Social, cultural, and economic capital can be converted to symbolic capital, and then reconverted to economic capital through an economisation program. In the PKB, the economic, social, and cultural capital possessed by the kiai was converted by Gus Dur into symbolic capital: the kiai khos. This was done to improve his political bargaining position vis-à-vis the Central Axis. The PKB's political power itself was insufficient to support Gus Dur's position in parliament.

Gus Dur skilfully created new symbols within the political sphere. This indicates that Gus Dur was capable of using his habitus and transforming his social and cultural capital into political power. The role and charisma of the kiai khos were used in monumental and important political activities. Where the kiai khos were attendant, the media provided coverage, and thus in a short time they received 
national attention. Gus Dur and the kiai khos maintained mutually beneficial relationships. For the kiai, the title of kiai khos offered them social, political, and financial benefits. Gus Dur worked hard to ensure that the kiai khos became not only kiai pesantren, but also resected national figures. Meanwhile, the social and symbolic capital of the kiai khos offered Gus Dur political support and legitimacy. As in an orchestra, there existed mutual symbolism, with each voice reinforcing the other. Gus Dur was active in practical politics, promoting the aspirations of the kiai, while the kiai khos remained active in the spiritual domain and in gathering public support and legitimacy for Gus Dur.

The increased social and economic status of the kiai khos, from local figures to national ones, brought with it increased capital and solidified their position within the PKB (Ngatawi, 2009, p.178). The kiai khos, alongside Gus Dur, became important actors within the party. Their networks, as part of their social capital, were no longer limited to other kiai, but also included government officials and national entrepreneurs. Likewise, their capacity as kiai, as part of their cultural capital, became included in politics on a broader level, reaching the national scale. Previously, they had only used their capital to teach at their pesantren and give sermons within a certain distance of their schools. Their views regarding fiqh (Islamic jurisprudence), which had previously only been shared through such forums as bahtsul masa'ail and halaqoh among kiai, became part of the public discourse owing to widespread media coverage. The views of the kiai were no longer limited to fiqh ibadah, munakahat or muamalah, but also expanded to fiqh siyasah.

The positions of Gus Dur and the kiai khos after this expansion of the field can be seen from their different forms of capital. 
Table 2

The Positions of Gus Dur and the Kiai Khos Following the Expansion of the Field

\begin{tabular}{|c|c|}
\hline Name & Position, Reputation, and Power Influences \\
\hline $\begin{array}{l}\text { K. H. Abdurrahman } \\
\text { Wahid (Gus Dur) }\end{array}$ & $\begin{array}{l}\text { 1. The strong man in the NU and PKB } \\
\text { 2. Through his networks (including the patronage } \\
\text { of kiai/santri), genius, education, and career, he } \\
\text { positioned himself at the peak of authority among } \\
\text { ulama. This authority included the guideline } \\
\text { samina wa atha'na (listen and obey), as the ulama } \\
\text { are viewed as the heirs of the Prophet. As such, } \\
\text { the kiai were expected to listen to and obey Gus } \\
\text { Dur, rather than the opposite. If Gus Dur were to } \\
\text { listen to and obey the various kiai, it would only } \\
\text { be because their view reflected that of Gus Dur. } \\
\text { Where their views were opposed to his, he would } \\
\text { not follow. } \\
\text { 3. Gus Dur used the kiai khos discourse to support } \\
\text { his political legitimacy, improve his bargaining } \\
\text { power with the Central Axis and improve the } \\
\text { socio-economic status of the kiai khos and their } \\
\text { communities }\end{array}$ \\
\hline $\begin{array}{l}\text { K. H. Abdullah } \\
\text { Faqih }\end{array}$ & $\begin{array}{l}\text { 1. A senior and respected kiai (khos), influential both } \\
\text { in NU and in Langitan. } \\
\text { 2. The main reference for the Nahdliyin, particularly } \\
\text { as related to public interest; he studied in Mecca } \\
\text { under Sayyid Alwi bin Abbas al Maliki (the father } \\
\text { of Sayyid Muhammad bin Alwi al Maliki) } \\
\text { 3. The Langitan pesantren served as the basis for the } \\
\text { political consolidation of Gus Dur and the PKB. }\end{array}$ \\
\hline $\begin{array}{l}\text { K. H. Mas Muh } \\
\text { Subadar }\end{array}$ & $\begin{array}{l}\text { 1. Spokesman for the kiai khos, administrator of the } \\
\text { pesantren Roudlotul Ulum, Besuk Pasuruan, Rois } \\
\text { Syuriah NU (Pasuruan Branch), and Deputy } \\
\text { Syuriah of NU, East Java Branch. } \\
\text { 2. Education completed entirely within pesantren } \\
\text { (Besuk, Pasuruan and Lirboyo, Kediri, East Java) }\end{array}$ \\
\hline
\end{tabular}


K. H. Abdurrahman Chudlori
1. Administrator of the API Tegalrejo pesantren, Magelang, Central Java, an alumnus of the Ploso pesantren, Kediri, East Java.

2. The kiai khos who laid the foundation for kiai politics and head of the Syura Council of the PKNU's Central Administrative Council.

3. The API Tegalrejo pesantren is one of the most influential in Central Java.

\section{The Political Contestations of the Kiai}

Bourdieu understands the field as a place in which members of society and social groups compete to improve and maintain their positions, both in power and in the accumulation of economic, social, cultural, and symbolic capital. In such contestation, people's habitus plays a determinant factor, for it determines their ability to utilise their economic, social, cultural, and symbolic capital, as well as to accumulate these forms of capital (Dirdjosantojo, 1999, p. xxvi).

Through the lens of Bourdieu's theory of social practice, the PKB's second internal power may be seen as a symbolic contestation between Gus Dur and the kiai khos over the questions of constitutionality versus unconstitutionality, inclusive Islam versus exclusive Islam, and kiai khos versus kiai kampung. Those supporting Gus Dur viewed the non-activation of Alwi-Syaifullah and the holding of the PKB's Second National Caucus in Semarang as constitutional, while those following the kiai khos held the opposite view. Gus Dur insisted that the PKB had to be an inclusive party (as a representation of NU's own inclusiveness), and therefore could not use Islam as its sole basis; meanwhile, the kiai khos took a more exclusive view of Islam. According to the kiai, as a party founded by NU, the PKB had to be rooted in Aswaja Islam. The kiai did not approve of the term kiai khos, particularly its being contrasted with kiai kampung. They held that the distinction between kiai khos and kiai kampung was created by Gus Dur to promote his own political interests. 
Based on this explanation, it can be inferred that the PKB's second internal conflict was not static, but dynamic. The blocs of Dur and the kiai khos were competing for influence and the achievement of one single goal: victory. The habitus and capitals of these groups were highly visible in this contestation. Each claimed to have the strongest basis in the party's constitution and the most correct path. Each claimed that it was using its capital to cultivate influence among supporters and erode the influence of its opponents.

Contestations between different discourses were nothing new in NU. As a religious organisation (jam'iyyah diniyah), NU established several Lajnah Bahtsul Masa'il (special sections). Forum Bahtsul Masa'il accommodated diverse views that spanned the spectrum from approval to disapproval. As such, discussions and findings of fact, as well as the identification of Quranic grounds for decisions, required considerable time. Those supporting and opposing certain views would spend days debating their views using their religious citations. Where no resolution or compromise could be reached, decisions would be made following the two or three most common views, which were viewed as equally correct. The diverse views held by NU members would not be the basis for arguments. None were considered the most correct at the expense of others. All views could be considered correct, so long as they had a legitimate basis in figh. Fiqh occupied a central position in the social lives of NU members. In their everyday activities, including their political activities, they considered the fiqh perspective. Such attention is given to fiqh as it is considered the standard for determining whether or not an activity is acceptable. Fiqh, understood as knowledge of religious laws and their basis in scripture, granted all views - both pro and con-equal opportunities in the resolution of different problems. All views, pro and con, had strong arguments. This "agree to disagree" mechanism guaranteed a flexible decision making within the organisation (Wahid, 2007). As such, contestation was a deep-rooted tradition in pesantren.

The symbolic contestation between Gus Dur and the kiai 
khos during the PKB's second internal conflict reflected the internal dynamics of two different groups within the organisation. Gus Dur represented inclusive Islam (realistic), while the kiai khos represented exclusive Islam (idealistic). Each group had its own basis in fiqh. This symbolic contestation also reaffirmed the position of Gus Dur as the dominant class and the kiai as the marginal class. Gus Dur's dominance in the PKB also indicates the habitus and capital he held, including social, cultural, and symbolic capital: social capital in the form of national and international networks; cultural capital in the form of knowledge and scholarship; and symbolic capital in the form of formal and informal titles and awards.

The unilateral non-activation of Alwi-Syaifullah, the establishment of the PKB as an inclusive party not based solely in Aswaja Islam, and the delegitimisation of the kiai khos through the creation of alternative kiai (i.e. the kiai kampung) shows Gus Dur's power within the party. His cultural legitimacy, in the form of his relations and his structural offices (i.e., as head of the party administration's Syura Council), not only leant him a position of strength, but also accelerated his entry into what Robert Michels calls the "iron law of oligarchy". According to Michels, any democratic organisation, no matter how modern, cannot entirely reject tendencies and practices that suggest a non-democratic attitude. The most important characteristic of this oligarchic tendency in political parties is the leadership's tendency to ignore or reject all criticism (Michaels, 1984).

The kiai, meanwhile, felt uncomfortable with the authoritarian actions of Gus Dur. The kiai regularly provided advice during meetings intended to resolve the conflict within the PKB. They did not remain silent, simply praying and saying their remembrances (zikir), but actively spoke out. The kiai considered several of Gus Dur's controversial public policies, as head of the PKB's Syura Council, to have violated the party's constitution and religious norms. They believed that Gus Dur's personal dominance within the PKB would lead only to madharat, i.e. internal conflict. 
Responding to the advice of the kiai, Gus Dur not only showed opposition, but deliberately initiated more progressive manoeuvres by establishing the Majelis Silaturrahmi Ulama Rakyat (Masura, the Council for Social Interactions among the Ulama). This forum was intended to provide the kiai kampung with a means of discourse while simultaneously delegitimising the kiai khos. ${ }^{10}$ The kiai kampung were depicted as kiai who remained sincere in their public service, while the kiai khos were depicted as having become elites trapped by political intrigue, and thus distant from the common people. Gus Dur believed that the time of the kiai khos was over, and that they must be replaced with kiai kampung. The kiai kampung were small-scale kiai, leading such religious institutions as langgar, mushola, mosques, and small pesantren. In general, they were active at the grassroots, involved in activities and reaching places that were untouched by those in power. Kiai kampung were presented as best knowing the pulse of the common people. Although they had little social and cultural capital, the kiai kampung were intensively involved with the faithful. As such, they were seen as being uncontaminated by practical political interests, lacking political ambition and the desire to gain power and high office (Asfar, 2007).

The willingness of the kiai khos to criticise the controversial actions of Gus Dur emerged after the latter declared the PKB to be inclusive, unilaterally non-activated Alwi Shihab-Syaifullah Yusuf, and held the Second National Caucus in Semarang. This was followed by a shift in political support to Alwi Shihab, extraordinary as to that point they had approved of Gus Dur's political activities. According to the kiai, Gus Dur's political activities were reckless and unconstitutional, and his personal dominance would lead to sub-optimal party operations (Arifin, 2008, p.151). Borrowing from

10 Information on the activities and establishment of Masura is available through the newsletters accessible on www.dpp-pkb.org. Including "Tujuh Ribu Kiai Kampung Ngaji Bersama Wahid" and "Wahid: Kiai Harus Senantiasa Bersama Rakyat," first newsletter, pp. 8-9. "Masura Jawa Timur: Kiai Kampung Padati Masjid Sunan Ampel", and "Masura Jawa Tengah: Kaum Muslimin Juga Harus Mengetahui Makna Al-Qur'an”, May 2007 newsletter, p. 5 . 
Max Weber's concept of charisma, Gus Dur's charisma could not be institutionalised in a permanent form, as doing so would sever the inter-institutional relations provided for within the PKB's constitution. This can be seen, for example, in the special position taken by the PKB's Syura Council while it was under the leadership of Gus Dur, who was simultaneously a member of the Tanfidz Council, the party's main decision-making body. Gus Dur, thus, had a determinant role in setting party policy (Analisis, 1994).

Regarding the contestation between Gus Dur and the kiai khos, Choirul Anam stated that the fragmentation between them was no longer a mere difference of opinion. As he argued:

There was an anti-climax of sorts in the relationships between the senior kiai and Gus Dur, leading to a situation of mufaraqoh (self-segregation). It appeared that it was no longer a simple difference of opinion, but rather at the level where they were evaluating their differences, using a syar'iy perspective. Were Gus Dur's attitudes towards socio-political, religious, and social issues still at a tolerable level of differences? Could they still be followed by the faithful? Or were they already too deviant, and thus should no longer be followed? (Choirul Anam, Personal communication, July 2013). ${ }^{11}$

\section{Similarly, K. H. Abdurrahman Chudlori-a kiai khos who headed the PKB's Syura Council for Surabaya—stated:}

... the party has exhibited behaviour that has deviated far from the political ideals of the kiai. As a result, the kiai, prominent figures in the NU, have agreed that the party cannot be used as a tool in its political struggles. Because it has deviated too greatly from the motivation for its establishment, including in its behaviour, platforms, structures, and-primarily-ideology ...(Chudlori, 2007, pp 7-20). ${ }^{12}$

11 Choirul Anam, Chairman of the PKNU Central Administrative Council. See also Zaim and. Kaiyis (2007.), pp. iii-iv.

Original: Ada semacam antiklimaks (kekecewaan) dalam relationship (hubungan pertalian) antara kiai sepuh dan Gus Dur sehingga melahirkan sikap mufaraqoh (memisahkan diri). Dan agaknya, kali ini bukan lagi sekedar perbedaan pendapat. Melainkan sudah pada tahap penilaian terhadap perbedaan itu sendiri, dari sudut pandang syar'ii. Apakah sikap-sikap Gus Dur terhadap berbagai persoalan sosial politik, keagamaan, dan kemasyarakatan selama ini masih dalam domain wilayah-perbedaan pendapat yang bisa ditolerir atau tidak? Masih bisa dianut umat atau tidak? Atau, sudah terlampau jauh berada pada wilayah penyimpangan yang tidak perlu lagi diikuti?

12 Original: ... partai ini mempertontonkan tingkah laku yang melenceng jauh dari cita-cita 
Pursuant to the pesantren habitus, which taught that all forms of madharat had to be eliminated, the actions of these kiai were understood as an affirmation of truth and justice (iqomatul haq wal 'adl). The non-activation of Alwi-Syaifullah, the holding of the caucus in Semarang, and the declaration that PKB would be inclusive were all seen as ignoring the advice of the kiai who had helped establish the party. The kiai continuously sought to improve the $\mathrm{PKB}$ and provide advice to Gus Dur. Various meetings were held, facilitated by the kiai, who sought to improve the party. As some of its founders, the kiai were unwilling to let the PKB collapse owing to poor management.

\section{Strategies for Shifting Political Support: Social Praxis}

The shift in political support to Alwi Shihab indicated the end of the mutual symbiosis between Gus Dur and the kiai khos, as well as the establishment of mutually beneficial relations between Alwi Shihab and the kiai khos. This occurred as Gus Dur's charisma eroded and the kiai khos gained increased legitimacy. As such, where during the PKB's first internal conflict all of the kiai had backed Gus Dur, during the second internal conflict, almost all of the kiai abandoned him. Gus Dur lost his main support: the kiai khos, who were well respected among NU members and had loyally supported him in politics and in conflict. After this shift in political support, there were no longer any senior or charismatic kiai on whom he could rely or whom he could respect. Although several party elders, including K. H. Mustofa Bisri and K. H. Muchit Muzadi, showed their concern, they were those he had frequently met or who had advised him, or who truly supported him in his political activities and his conflicts (Noor, 2015, p.238).

Meanwhile, Alwi's bloc gained political legitimacy through

politik kiai. Akibatnya para kiai yang merupakan tokoh-tokoh NU terkemuka bersepakat bahwa partai ini tidak dapat dijadikan sebagai alat perjuangan politiknya. Karena, sudah menyimpang dari rancang bangun partai politik yang diharapkan baik dari sisi perilaku, platform, struktur dan terutama ideologi... 
the blessings of the kiai khos, who in turn received economic blessings. This represented a mutual symbiosis between them. As the kiai khos discourse became increasingly entrenched, government officials and entrepreneurs frequently met them at their pesantren, seeking to further various interests. Their presence brought with it various logistics and material benefits for the pesantren and the families of the kiai. The de-legitimisation of the kiai khos by Gus Dur, perpetrated through the discourse of kiai kampung proved ineffective. Although Gus Dur considered the National Caucus of Alim Ulama and the PKB Central Administrative Council Working Meeting, held in Surabaya in 2005, to be improper, these were still capable of drawing numerous kiai. The kiai khos, through their symbolic capital, still had considerable influence, and thus attracted a number of religious leaders: 1,220 participants in total, with 714 kiai, including 25 kiai khos, and 406 non-kiai participants. ${ }^{13}$

Regarding the meetings held by the kiai khos to improve the PKB, K. H. Anwar Iskandar, the head of the Syura Council in the party's East Java branch:

The kiai joined together not to speak about individuals. Not to talk about Gus Dur, Muhaimin, Alwi Shihab, or Gus Ipul, but they were united to straighten that which was out of shape. This party $(\mathrm{PKB})$ has gone off the rails. If this were let be, the party would have no future, as it would not be managed by a system, but only by likes and dislikes. And that would be dangerous. As such, the kiai have united to seek a means of fixing that which has gone wrong. ${ }^{14}$

13 Choirul Anam, the Committee Chairman, stated that after K.H. Abdullah Faqih, the most influential kiai within the Forum Langitan, gave his blessings and permission for the 2005 National Caucus of Alim Ulama and the PKB Central Administrative Council Working Meeting, all of his supporters and santri came to attend the event. The National Caucus was attended by 714 kiai, including 25 kiai khos; the Central Administrative Council Meeting was attended by 28 Regional Leadership Councils (140 total attendees). Furthermore, the PPKB sent a delegation of 36 people, Garda Bangsa sent 50 people; and 150 people came from the 30 PKB Regional Councils in East Java. See "Speech of the Committee Chairman, of the National Caucus of Alim Ulama and the PKB Central Administrative Council Working Meeting", 1-2 October 2005, Surabaya, pp. vi-vii.

142005 National Caucus of Alim Ulama and the PKB Central Administrative Council Working Meeting documentation, Surabaya, p. 181.

Original: Para kiai berkumpul dengan semangat bukan bicara orang per orang. Bukan 
According to the kiai, the rationales cited and procedures for the non-activation of Alwi Shihab and Syaifullah as the party's chairman and secretary general (respectively) were unjust, unilateral, and went against party policy. The kiai, through the National Caucus, hoped to send Gus Dur another reminder and help Alwi-Syaifullah regain their positions.

Similarly, K. H. Idris Marzuki stated:

The ulama supported this Working Meeting based only on a desire to improve and ndandani (beautify) the $\mathrm{PKB}$, so it can become a good party in the eyes of the ulama, in accordance with the awakening of the faithful (nuhudlul ummah) and our supporters, most of whom are with the NU. So not according to the opinions of just one person. Once the duties of the ulama and kiai is to guide and improve the party as a vehicle for its people are concluded, it is clear that the ulama will return to their everyday activities: prayers, teaching, and other activities. And this is the important role and function of the ulama in improving (ishlah) the social lives and politics of the faithful. ${ }^{15}$

Based on this discussion, it may be concluded that the criticism of Gus Dur's controversial activities and shift in political support to Alwi Shihab was not an opportunistic power grab. The kiai, rather, sought to improve the party that represented them and all members of the NU. The political activities of the kiai khos were

bicara soal Gus Dur, Muhaimin, Alwi Shihab, atau Gus Ipul, tapi substansi semangat para kiai adalah bagaimana meluruskan yang bengkok. Partai ini (PKB), sudah keluar dari rel. Kalau dibiarkan, partai ini tidak akan punya masa depan karena tidak diatur dengan sistem. Tapi hanya melayani dengan like dan dislike. Dan itu berbahaya. Karena itu, kiai-kiai berkumpul untuk mencari solusi guna meluruskan yang bengkok-bengkok tadi.

15 Welcoming speech of the Syura Council PKB Central Administrative Council, K.H. Idris Marzuki, at the National Caucus of Alim Ulama and the PKB Central Administrative Council Working Meeting 2005.

Original: Para ulama ikut serta mendukung pelaksanaan Mukernas hanyalah berdasarkan keinginan untuk memperbaiki sekaligus ndandani $\mathrm{PKB}$ agar menjadi partai yang baik menurut para ulama, menurut kebangkitan umat (nuhudlul ummah) dan para pendukungnya yang mayoritas warga NU. Jadi tidak menurut hanya seorang saja. Jika tugas ulama dan kiai mengantarkan dan ndandani partai yang menjadi wadah umatnya sudah selesai, maka sudah barang pasti, ulama akan kembali ke dunianya sehari-hari, yakni pengajian, pendidikan dan aktivitas lainnya di tempatnya masing-masing. Dan inilah pentingnya peran dan fungsi ulama dalam proses perbaikan (ishlah) di wilayah kehidupan sosial kemasyarakatan dan perpolitikan umat. 
thus in accordance with the pesantren habitus, specifically Aswaja Islam, which positioned politics as a means of affirming truth and justice (iqomatul haq wal 'adl). Their shift in political support can also be recognised as an attempt to contest their symbolic capital, assert their own position in the PKB, and advise Gus Dur. Their sharp criticism of Gus Dur was not rooted in hatred; as stated by one kiai to Alwi Shihab in Surabaya in 2005, the kiai still loved Gus Dur, but their love for truth was greater than their love for him (nahnu nuhibbu Gus Dur walaakinnal haqqa ahabbu ilaina min Gus Dur). ${ }^{16}$ The political activities of the kiai khos, i.e. the criticism of Gus Dur's controversial activities and shift of political support towards Alwi Shihab in the PKB's internal conflicts, can be summarised as in the following table:

Table 3:

Political Activities of Kiai Khos as Social Praxis

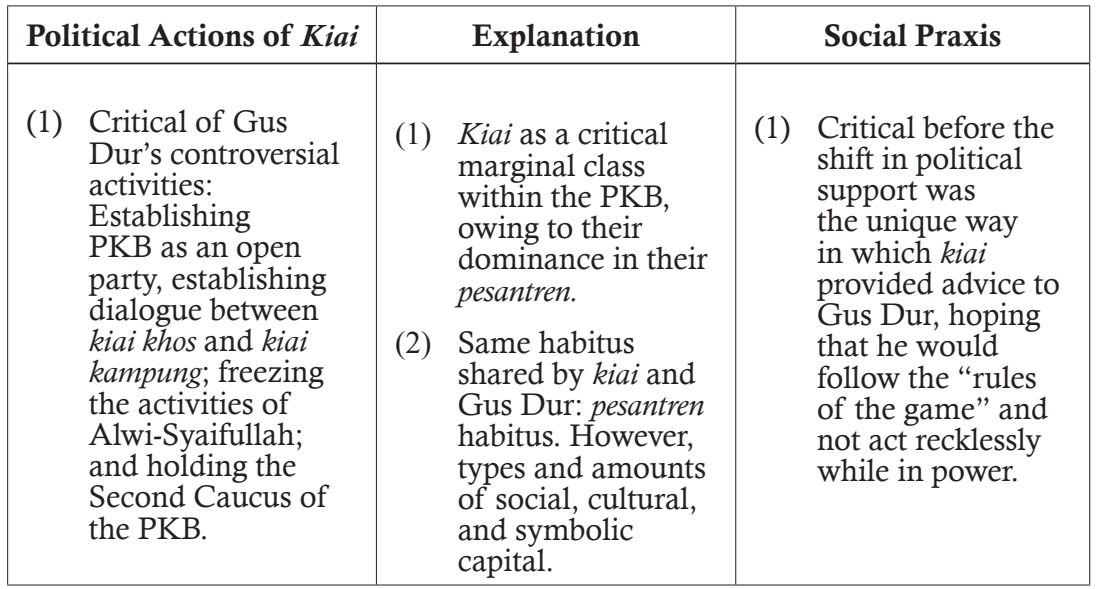

16 Speech of Alwi Shihab as Chief of the PKB Central Administrative Council (AlwiSyaifullah Group) at the Opening of the National Caucus of Alim Ulama and the PKB Central Administrative Council Working Meeting 2005 at the Sukolilo Hajji Dormitory, Surabaya, 27-29 May 2005. 


\begin{tabular}{|c|c|c|c|}
\hline Political Actions of $\mathrm{Kiai}$ & Explanation & & Social Praxis \\
\hline $\begin{array}{l}\text { (2) Shifting political } \\
\text { support to Alwi } \\
\text { during internal } \\
\text { conflicts within the } \\
\text { PKB. }\end{array}$ & $\begin{array}{l}\text { (3) Different types } \\
\text { and amounts of } \\
\text { social and cultural } \\
\text { capital, influencing } \\
\text { different } \\
\text { understandings of } \\
\text { Islamic political } \\
\text { parties. }\end{array}$ & $\begin{array}{l}(2) \\
\\
\text { (3) }\end{array}$ & $\begin{array}{l}\text { Alwi-Syaifullah } \\
\text { received support } \\
\text { as they worked } \\
\text { intensively to } \\
\text { approach kiai in } \\
\text { a humanitarian } \\
\text { manner, while } \\
\text { Gus Dur used } \\
\text { a confrontative } \\
\text { approach. } \\
\text { Shift of political } \\
\text { support to } \\
\text { Alwi Shihab } \\
\text { as peak of kiai } \\
\text { disappointment } \\
\text { towards the } \\
\text { controversial } \\
\text { activities of Gus } \\
\text { Dur. }\end{array}$ \\
\hline
\end{tabular}

\section{Conclusion}

The results of this study have identified changes in the political activities of the kiai khos. Although they had previously supported the political activities of Gus Dur, including in PKB's internal conflicts, they became critical and shifted their political support to Alwi Shihab in the party's internal conflicts, not owing to poweroriented opportunism, but social praxis a la kiai. A political praxis emerged from the dialectics between the creative strategies of the kiai and their use of symbolic capital within the PKB, where the kiai applied their habitus, i.e. Aswaja Islamic values. Pursuant to the pesantren habitus, politics was used as a tool for promoting truth and justice (Iqomatul Haq wal 'adl). The kiai attempted to create balance by applying the pesantren habitus within political life, to ensure that the PKB remained a party that followed the values and promoted the goals of Aswaja Islam.

The findings of this research have revised the results of previous studies into the political activities of kiai within the context of PKB's internal conflicts, which argued that the shift in 
political support towards Alwi Shihab represented a new form of opportunism among the kiai of NU. The results of this research have shown that the political activities of the kiai khos involved advising Gus Dur to control his ego, to position himself appropriately, and to be consistent when leading and administering the PKB. 


\section{References}

Analisis Fachri Ali. (1994, November 26). Gatra, P. 19.

Anand, P., Pattanaik, P., \& Puppe, C. (eds.). (2009). The Handbook of Rational and Social Choice. New York: Oxford University Press.

Arifin, I. (2008). Kiai dan Politik : Studi Kasus Perilaku Politik Kiai dalam Konflik PKB Pasca Muktamar II Semarang (unpublished thesis). Diponegoro University, Indonesia.

Asfar, M. (2007, February, 18). Gus Dur dan Kiai Kampung. Suara Merdeka, p. 8

Asy'ari, S. 2010. Nalar Politik NU \& Muhammadiyah: Over Crossing Java Sentris. Yogyakarta: LKiS.

Bourdieu, P. (1984). Distinction : A Social Critique of the Judgment of Taste. London: Roulledge

Bourdieu, P., \& Waqcuant, L. (1992). An Invitation to Reflexive Sociology. Chicago: The University of Chicago Press

Bourdieu, P. (1992). The Logic of Practice. Stanford - Calif : Stanford University Press.

Bourdieu, P. (1995). Language and Symbolic Power. Cambridge: Polity Press.

Brackman, A. C. (1963). Indonesian Communism: A History. New York: Frederick A. Praeger.

Bungin, B. (2007). Penelitian Kualitatif: Komunikasi, Ekonomi, Kebijakan Publik dan Ilmu Sosial Lainnya. Jakarta: Kencana.

Chudlori, A. (2007). Politik Kiai dan PKNU. Jakarta: DPP PKNU.

Coleman, S. J. (2010). Dasar-Dasar Teori Sosial. Bandung : Nusa Media.

Dirdjosanjoto, P. (1999). Memelihara Umat: Kiai Pesantren, Kiai Langgar di Jawa, Yogyakarta: LkiS.

Fealy, G. (2009). Ijtihad Politik Ulama: Sejarah NU 1952-1967. Yogyakarta: LKiS.

Febrina, R.H., Mustika, B.U., \& Dedees, A.R. (2014). Nahdlatul Ulama: Bebas untuk Oportunis? Menelisik Kontestasi Politik pada Pemilihan Kepala Daerah Kabupaten Banyumas Periode 2008 dan 2013. Jurnal Ilmu Sosial dan Ilmu Politik, 18, (2), 116-129.

Geerzt, C. (1959). The Javanese Kyai: The Changing Role of Cultural Broker. Comparative Studies in Society and History, (2), 250-256.

Geerzt, C. (1960). The religion of Java. New York: The Free Press Glenceo. Horikoshi, H. (1987). Kiai dan Perubahan Sosial. Jakarta: P3M.

Ijtihad. (1990). In Kamus Besar Bahasa Indonesia. Jakarta: Balai Pustaka. 
Kamarudin. (2013). Konflik Internal Partai Politik: Studi Kasus Partai Kebangkitan Bangsa. Jurnal Penelitian Politik, 10 (1), 29-39.

Lev, D.S. (1966). The Position to Guided Democracy Indonesia Politics, 19571959. Ithaca: Cornell Modern Indonesia, Project.

Michaels, R. (1984). Partai Politik: Kecenderungan Oligarkis Dalam Birokrasi. Jakarta: Rajawali Press.

Muhajir, A. (2007). Idham Cholid Guru Politik Orang NU. Yogyakarta: Pustaka Pesantren.

Mulkan, A.M. (1992). Runtuhnya Mitos Politik Santri. Jakarta: Siepress.

Naim, M. (1960). The Nahdlatul Ulama as a Political Party, 1952-1955: An Enquiry into the Origins of Its Electoral Succes. Thesis: McGill University.

Ngatawi. (2009). Modalisasi Simbol Agama: Studi Atas Fenomena Kelas Transkultural Komunitas Pesantren (unpublished doctoral thesis). University of Indonesia, Indonesia.

Noer, D. (1994). Gerakan Modern Islam di Indonesia: 1900-1942. Jakarta: LP3ES.

Noor, F. (2015). Perpecahan dan Solidaritas Partai Islam : Kasus PKB dan PKS di Dekade Pertama Reformasi. Jakarta : LIPI Press.

Rakhmat, J. (1999). Rekayasa Sosial Reformasi atau Revolusi?. Bandung: Rosda.

Ritzer, G. (2012). Teori Sosiologi dari Sosiologi Klasik Sampai Perkembangan Terakhir Teori Sosial Postmodern. Yogyakarta : Kreasi Wacana.

Suprayogo, I. (1998). Kiai Politik, Kiai Advokatif dan Kiai Spiritual (unpublished doctoral thesis). Airlangga University, Indonesia.

Turmudi, E. (2004). Perselingkuhan Kiai dan Kekuasaan. Yogyakarta: LKiS.

Utrech, E. (1959). Pengantar Dalam Hukum Indonesia. Jakarta: Ikhtiar.

Wahid, A. (2007). Islam Kosmopolitan : Nilai-nilai Indonesia dan Transformasi Kebudayaan, Jakarta : Wahid Institute.

Wartono. (2003). Wacana Politik Kiai Pada Era Pemerintahan Gus Dur: Apakah Sebagai Intelektual Organik atau Tradisional (unpublish doctoral thesis). Airlangga University, Indonesia.

Zaim, A. \& Kaiyis, M. (Ed). (2007). 9 Alasan Mengapa Kiai-Kiai Tidak Lagi Bersama Gus Dur. Jakarta: DPP PKNU. 